\author{
NATALIA HAEAS \\ Pracownia Ekologii Populacyjnej \\ Instytut Biologii Środowiska \\ Wydziat Biologii \\ Uniwersytet im. Adama Mickiewicza w Poznaniu \\ Umultowska 89, 61-614 Poznań \\ Ogród Botaniczny Uniwersytetu im. Adama Mickiewicza w Poznaniu \\ Dabrowskiego 165, 60-594 Poznań \\ E-mail: natalia.krolikowska@amu.edu.pl
}

\title{
KONSEKWENCJE PRZEMIAN GOSPODARKI ROLNEJ I TRANSFORMACJI KRAJOBRAZU ROLNICZEGO DLA PTAKÓW SZPONIASTYCH
}

\section{WSTEP}

Człowiek może oddziaływać na środowisko przyrodnicze na wiele sposobów. Jego działalność przekształca ekosystemy w skali globalnej i zazwyczaj prowadzi do degradacji i bezpowrotnej utraty siedlisk pierwotnych (TILMAN i współaut. 2001, TSCHARNTKE i współaut. 2005). Z drugiej strony, antropogeniczne transformacje środowiska przyczyniaja się do powstawania nowych typów siedlisk. Choć często reprezentuja one siedliska suboptymalne, wiele organizmów jest w stanie je zasiedlić i realizować wszystkie swoje funkcje życiowe, adaptując się stopniowo do presji antropogenicznej (SAUNDERS i współaut. 1991, MARZLUfF 2001). Agrocenozy zastapiły wiele siedlisk pierwotnych: lasy, obszary stepowe i naturalne laki (URSÚA i współaut. 2005, LAIOLO i TELLA 2006). Utrata pierwotnie zajmowanych siedlisk zmusiła wiele gatunków ptaków obecnie zagrożonych w skali kontynentu do zasiedlenia tego środowiska zastępczego (PAIN i PIENKOWSKI 1997). Agrocenozy, mimo że stanowią siedlisko pochodzenia antropogenicznego, moga charakteryzować się wysoką wartością i różnorodnością biologiczną, będąc miejscem wysteppowania wielu unikatowych zespołów gatunków (PAIN i PIENKOWSKI 1997, HENLE i współaut. 2008).

Długa historia rolnictwa w Europie wiąże się $z$ transformacjami, które podążały za zmianami politycznymi. Najpoważniej- sza $z$ dotychczasowych rewolucji rolniczych rozpoczęła się $\mathrm{w}$ połowie XX w. i trwa do dziś (BlaXter i ROBERTSON 1995, DONALD i współaut. 2001). Przemiany europejskiego rolnictwa pociagnęły za soba spadek liczebności populacji ptaków (np. DONALD i współaut. 2001), ssaków (np. MiLláN DE LA PEÑA i współaut. 2003), bezkręgowców i roślin kwiatowych (np. VICKERY i współaut. 2001), skutkujac zubożeniem fauny i flory $w$ porównaniu do stanu $z$ początku $X X$ w. (TSCHARNTKE i współaut. 2005, STORKEY i współaut. 2012). Szacuje się, że od lat 70. populacje ptaków krajobrazu rolniczego zmniejszyły się niemal o połowę (BUTLER i współaut. 2007, PECBMS: http://www.ebcc. info/pecbm.html). Niektóre europejskie gatunki zmniejszyły liczebność i zasięg występowania o ponad $80 \% \mathrm{w}$ ciagu niespełna 20 lat (CHAMBERLAIN i współaut. 2000, NEWTON 2004). KREBS i współaut. (1999) jako pierwsi zwrócili uwage na drastyczne spadki liczebności ptaków krajobrazu rolniczego, przestrzegajac przed zjawiskiem drugiej cichej wiosny (ang. second silent spring), efektem negatywnego oddziaływania intensyfikacji i industrializacji. Tak niekorzystnych trendów nie obserwuje się u gatunków związanych $z$ innymi typami siedlisk (CHAMBERLAIN i SIRIWARDENA 2000).

Zmiany w sposobach prowadzenia gospodarki rolnej powoduja przekształcenia krajobrazu rolniczego i wywieraja znaczacy, negatywny wpływ na ptaki oraz agroceno-

Słowa kluczowe: intensyfikacja rolnictwa, krajobraz rolniczy, ochrona ptaków krajobrazu rolniczego, ptaki szponiaste, ubożenie siedlisk 
zy, jako środowisko życia wielu organizmów. Przejawia się on modyfikacją siedlisk, presja antropogeniczna, wpływem na zespoły drapieżników oraz kondycję i fizjologię ptaków (STERNALSKI i współaut. 2013). W niniejszej pracy postanowiłam skoncentrować się na wpływie intensyfikacji rolnictwa na ptaki szponiaste Accipitriformes. Oddziaływanie zmian w rolnictwie podzieliłam na: (i) bezpośrednie, przejawiające się fizycznym niszczeniem miejsc rozrodu, prowadzacym do śmierci młodych i osobników dorosłych, i (ii) pośrednie, które obejmuje: wywieranie presji na zajmowane siedliska (ich dostępność i jakość) i zasoby pokarmowe (ich ilość, jakość i dostępność) oraz oddziaływanie środków chemicznej ochrony roślin na ptaki.

\section{HISTORIA INTENSYFIKACJI GOSPODARKI ROLNEJ W POLSCE I W EUROPIE}

W niektórych państwach intensyfikacja produkcji rolnej wiązała się $z$ ustrojem politycznym, np. $z$ komunizmem w krajach dawnego bloku wschodniego. Po przemianach politycznych ulegała jednak gwałtownym zmianom, najczęściej w kierunku bardziej ekstensywnej formy gospodarki (obniżenie dochodów w rolnictwie i niższe nakłady finansowe $\mathrm{w}$ tym sektorze skutkowały $\mathrm{np}$. mniejszym zużyciem nawozów sztucznych i ograniczeniem mechanizacji) (STOATE i współaut. 2009). W Anglii proces intensyfikacji produkcji rolnej wymuszony był odizolowaniem państwa od kontynentu europejskiego w okresie II Wojny Światowej. Jednak poczatek okresu najbardziej wzmożonych przemian rolnictwa, obejmujaccy w szczególności państwa założycielskie Unii Europejskiej (UE), przypadł na 1971 r. (CHAMBERLAIN i współaut. 2000).

Wielu autorów uznaje, że zjawisko intensyfikacji rolnictwa przyjęło najdotkliwsza w historii formę na skutek wdrożenia Wspólnej Polityki Rolnej (WPR), które towarzyszyło powojennej integracji europejskiej (TElla i współaut. 1998, Donald i współaut. 2001). WPR stanowi jednak dynamiczny twór i ulega modyfikacjom w odpowiedzi na aktualne problemy, coraz więcej uwagi poświęcając działaniom na rzecz zahamowania utraty różnorodności biologicznej obszarów rolnych (OvERMARs i współaut. 2014). Mimo tego, efektem wielu lat członkostwa w UE i intensywnej gospodarki rolnej jest niemal zupełny zanik ekstensywnego rolnictwa w krajach założycielskich UE (HENLE i współaut. 2008, STOATE i współaut. 2009). W większości państw członkowskich tradycyjna gospodarka rolna stanowi jedynie marginalny system ekonomiczny (MACEDO-SOUSA i współaut. 2009). Tradycyjne, sprzyjajace wysokiej różnorodności biologicznej rolnictwo utrzymuje się jeszcze lokalnie w Europie Wschodniej dzięki ekonomicznej i technologicznej izolacji tego regionu w okresie powojennym (BÁlDI i BATÁRY 2011, TRYJANOWSKI i współaut. 2011). Państwa Europy Centralnej i Wschodniej (Bułgaria, Czechy, Wegry, Polska, Rumunia i Słowacja) charakteryzuja się niższym wkładem agrochemii, niższa mechanizacja i mniejszym uzyskiem w przeliczeniu na hektar, niż państwa założycielskie UE (CSÁKI i JÁMBOR 2013, SUTClIFFE i współaut. 2015). Jednocześnie cechują się wyższą w skali kontynentu różnorodnościa biologiczna z większa liczba gatunków rzadkich i zagrożonych (BIRDLIFE INTERNATIONAL 2004, OVERMARS i współaut. 2014).

W Polsce wzrost intensywności produkcji rolnej nastapił po II Wojnie Światowej. Utworzono wówczas Państwowe Gospodarstwa Rolne (PGR), które poczatkowo powstawały $\mathrm{w}$ miejscu poniemieckich majątków ziemskich, a w późniejszym okresie także opuszczonych gospodarstw oraz gruntów instytucji państwowych i kościelnych. Reorganizacja i konsolidacja gospodarstw w większe jednostki przyczyniała się do powiększania ogólnej powierzchni PGRów do 4,3 mln ha w latach 70. W północnej i zachodniej Polsce w latach 80. w majątku PGRów znajdowało się ponad 50\% użytków rolnych. Od lat 70. rósł także udział gospodarstw indywidualnych, których powierzchnia zajmowała $75 \%$ ogólnej powierzchni użytków rolnych w latach 80. Transformacja polskiego rolnictwa na początku lat 90. spowodowała likwidację PGRów. Ostatnie państwowe gospodarstwa zamknięto w 1994 r. Rozpoczął się wówczas okres pogorszenia sytuacji ekonomicznej rolnictwa - dochody gospodarstw spadły o $40 \%$ (BAŃSKI 2009). Jednocześnie znaczaco zwiększyła się powierzchnia obszarów odłogowanych i ugorowanych. Wzrost intensyfikacji produkcji rolnej nastapił ponownie w miarę zbliżania się akcesji Polski do UE i postępuje do dziśs.

Zgodnie $z$ badaniami GuerRero i współaut. (2011), Polska charakteryzuje się, spośród 7 analizowanych państw, najwyższym bogactwem gatunków ptaków gniazdujacych na ziemi i utrzymuje duże populacje ptaków krajobrazu rolniczego (BIRDLIFE INTERNATIONAL 2004), co odpowiada długiej dominacji ekstensywnego rolnictwa w naszym kraju (SCIERCIU 2011). Prognozuje się jednak, że postępujacca intensyfikacja rolnictwa doprowadzi do nasilenia niekorzystnych zjawisk populacyjnych także w tym regionie Europy (SuTCLIFFE i współaut. 2015). Wyniki monitoringu prowadzonego $\mathrm{m}$. in. w Polsce, na Łotwie i Wegrzech wykazuja przyspieszanie 
spadku liczebności populacji niektórych gatunków, potwierdzając pesymistyczne prognozy (SANDERSON i współaut. 2013, SUTCLIFFE i współaut. 2015). Choć kraje Europy Centralnej i Wschodniej stanowia rezerwuar różnorodności biologicznej krajobrazu rolniczego (SuTCLIFFE i współaut. 2015), wiedza o mechanizmach oddziaływania przemian gospodarki rolnej na gatunki ptaków i o stanie ich populacji pochodzi przede wszystkim z Europy Zachodniej (TRYJANOWSKI i współaut. 2011, SuTCLIFFE i współaut. 2015).

\section{MECHANIZMY ODDZIAŁYWANIA INTENSYFIKACJI ROLNICTWA}

Intensyfikacja rolnictwa jest procesem złożonym i wiąże się $z$ : (i) zwiększeniem zużycia środków chemicznych (pestycydów, nawozów sztucznych), (ii) przyspieszeniem terminów zbioru plonów (wskutek nawożenia i wcześniejszych zasiewów), (iii) zanikiem zadrzewień śródpolnych, miedz i ugorów (dla zwiększenia powierzchni rolnej), (iv) wzrostem powierzchni monokultur i utrata zróżnicowania upraw w dużej skali, (v) zanikiem rolnictwa małoobszarowego i scaleniem niewielkich gospodarstw rolnych do farm o dużej powierzchni, (vi) zwiększeniem powierzchni zasiewów zbóż ozimych kosztem jarych, (vii) wzrostem powierzchni upraw rzepaku (w Polsce powierzchnia upraw rzepaku niemal podwoiła się w okresie 20012011 do poziomu 8\% zasiewów; Gus 2012), (viii) zwiększonym osuszaniem gleb w dolinach i nawadnianiem siedlisk suchych, (ix) rozwojem technologii w zakresie maszyn rolniczych (CHAMBERLAIN i współaut. 2000, VICKERY i współaut. 2001, FOLEY i współaut. 2005, GREEN i współaut. 2005, TSCHARNTKE i współaut. 2005, KLEIJN i współaut. 2009, STOATE i współaut. 2009, BUTLER i współaut. 2010, GONZÁLEZ-ESTÉBANEZ i współaut. 2011, SuTCLIFFE i współaut. 2015).

Wpływ przekształceń gospodarki rolnej wydaje się być najbardziej złożony w przypadku ptaków szponiastych, charakteryzujacych się dużymi areałami osobniczymi i zajmujacych szczytowe pozycje łańcucha pokarmowego. Ze względu na presję oddziaływań antropogenicznych w szerokim gradiencie wybiórczości środowiskowej (skala krajobrazowa, skala areałów osobniczych, skala mikrosiedliskowa - miejsce gniazdowania), ptaki szponiaste stanowia dobre wskaźniki dla monitoringu zmian na poziomie ekosystemów (Tella i współaut. 1998, CARRETE i współaut. 2009). Jako grupa często związana $z$ obszarami o wysokiej różnorodności biologicznej, ptaki szponiaste moga stanowić także wskaźnik rolnictwa o wysokiej wartości biologicznej (tzw. high-nature value farmland) (GREGORY i współaut. 2005, SERGIO i współaut. 2008, MORELLI i współaut. 2014). Do prawidłowej interpretacji konieczna jest jednak głęboka znajomość ich ekologii, preferencji siedliskowych i mechanizmów odpowiedzi na antropopresję w agrocenozach, a ta w przypadku wielu gatunków (w szczególności tych mniej charyzmatycznych) jest nadal niewystarczająca (LóPEZ-LóPEZ i współaut. 2016).

\section{BEZPOŚREDNI WPEYW \\ INTENSYFIKACJI ROLNICTWA NA SMIERTELNOŚC PTAKÓW SZPONIASTYCH}

Wskutek mechanizacji rolnictwa wzrosła liczba maszyn wykorzystywanych w pracach agrotechnicznych, a znaczny wzrost powierzchni zasiewów zbożami ozimymi od lat 70. (CHAMBERLAin i współaut. 2000) i zmiany klimatyczne przyspieszyły okres żniw i pokosów. W Wielkiej Brytanii udział zbóż jarych w ogólnej powierzchni upraw rolnych spadł $z$ 80\% w latach 60 . do $10 \%$ w 1994 r. (CHAMBERLAIN i SIRIWARDENA 2000). W 2006 r. termin żniw we Francji przypadał 2 tygodnie wcześniej niż w 1988 r. (TRIERWEILER i KOKS 2009), a w Holandii różnica ta wyniosła miesiąc pomiędzy rokiem 1968 a 2008 (TRIERWEILER i KOKS 2009). Zboża ozime dojrzewają szybciej niż zboża jare i w sprzyjajacych warunkach pogodowych moga być koszone już w czerwcu (KOLEČEK i współaut. 2015), w szczycie sezonu lęgowego np. błotniaka łakowego (Circus pygargus) (Ryc. 1). Intensywne nawożenie łąk powoduje szybki rozwój zwartej struktury roślinności, dzięki czemu koszenie odbywa się nawet kilka razy w ciągu sezonu lęgowego (VICKERY i współaut. 2001), uniemożliwiając błotniakom łakowym zakończenie lęgu $z$ sukcesem (Ryc. 2). Uprawy lucerny w Holandii koszone sa już w maju-czerwcu (KoKs i współaut. 2007), w okresie inkubacji i wykluwa-

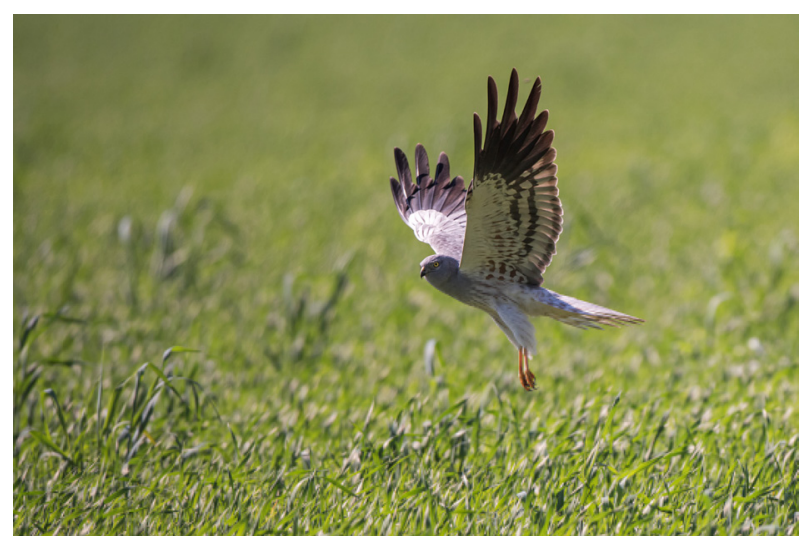

Ryc. 1. Polujący samiec błotniaka łąkowego (fot. A. Łukijańczuk). 


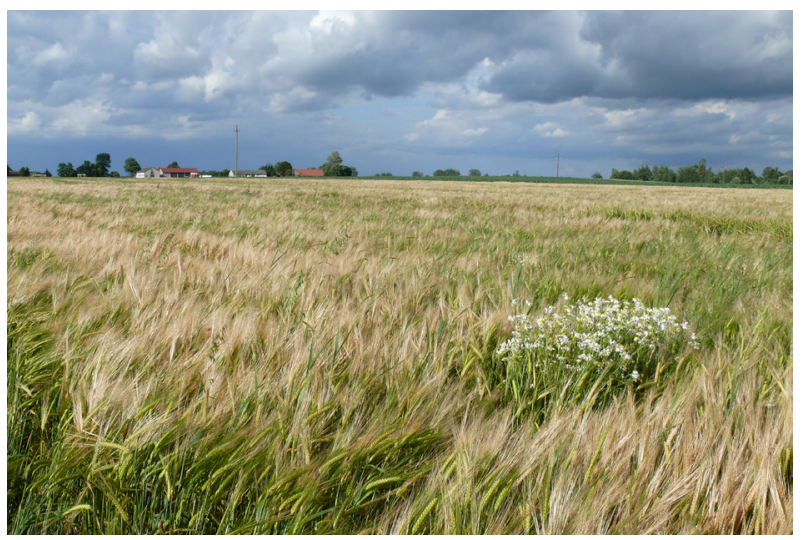

Ryc. 2. Siedlisko lęgowe błotniaka łakkowego (fot. N. Hałas).

nia się piskląt błotniaka łąkowego i innych gatunków ptaków gniazdujących na ziemi. Podczas mechanicznej orki, pokosów i żniw niszczone sa gniazda i całe lęgi (ARROYO i współaut. 2002, TEWs i współaut. 2013) (Ryc 3). Maszyny rolnicze rozjeżdżaja jaja i pisklęta, a niepotrafiace jeszcze sprawnie latać podloty błotniaka wpadaja pod koła maszyn, uciekajacc przed kombajnami (ARROYO i współaut. 2002, Krupiński inf. ustna). W czasie pokosów i żniw dochodzi niekiedy do śmierci wysiadujących samic (KoKs i współaut. 2007)

We Francji, Portugalii i Hiszpanii od 41 do $98 \%$ gniazd błotniaka łakkowego jest niszczonych przez maszyny rolnicze (ARROYO i współaut. 2002). We Francji i na Półwyspie Iberyjskim nawet $60 \%$ piskląt może ginąć pod kołami kombajnów i innych maszyn rolniczych (ARROYO i współaut. 2002, STERNALSKI i współaut. 2013). Przykryty skoszona roślinnością lęg staje się niedostępny dla dorosłych osobników i zostaje porzucony (BuCKINGHAM i współaut. 2015). Jeżeli gniazdo przetrwa żniwa, brak osłony roślin zwięk-

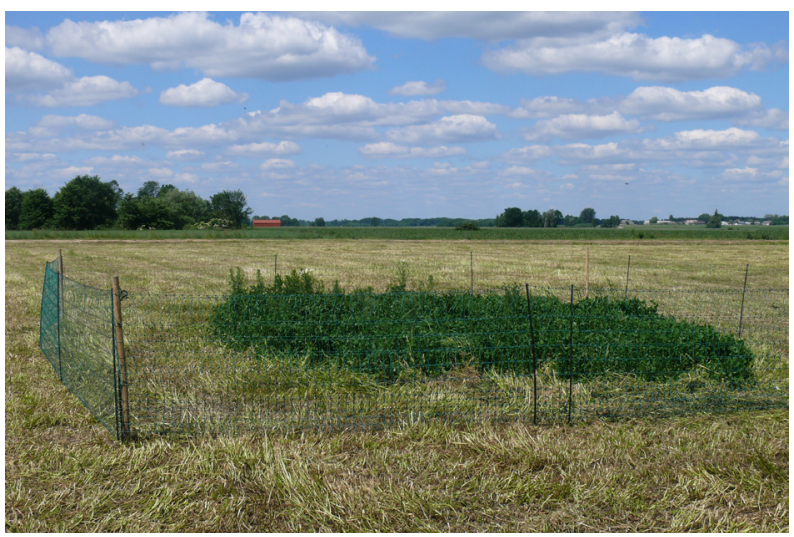

Ryc. 3. Gniazdo błotniaka łakkowego zabezpieczone ogrodzeniem przed skoszeniem i drapieżnictwem (fot. N. Hałas). sza jego ekspozycję i ryzyko drapieżnictwa (WhitTINGHAM i Evans 2004, Gillis i współaut. 2012). Z tego powodu żniwa i pokosy uznaje się za jedna $z$ głównych przyczyn spadku liczebności błotniaka łąkowego (np. ARROYO i współaut. 2003) i innych ptaków gniazdujacych na ziemi, np. kulika wielkiego (Numenius arquata), czajki (Vanellus vanellus), skowronka (Alauda arvensis) (PAIN i PIENKOWski 1997, TEWs i współaut. 2013).

\section{POŚREDNIE MECHANIZMY \\ ODDZIAŁYWANIA INTENSYFIKACJI \\ ROLNICTWA NA PTAKI SZPONIASTE}

\section{WPŁYW INTENSYFIKACJI ROLNICTWA NA SIEDLISKA LEGOWE}

W toku ewolucji zwierzęta wykształcaja mechanizmy wybiórczości środowiskowej i na podstawie specyficznych informacji płynących ze środowiska, zwiazanych zarówno ze struktura krajobrazu, jak i pochodzacych od innych organizmów, podejmuja decyzje o wyborze miejsca rozrodu. U ptaków szponiastych o rozległych areałach osobniczych, wybór miejsca jest procesem szczególnie skomplikowanym, gdyż odbywa się na kilku poziomach przestrzennych: areał musi zapewniać dogodne siedliska żerowiskowe oraz gniazdowe i miejsca do ukrycia. $Z$ tego względu wskazówki istotne dla ptaków w procesie osiedlania się są bardziej złożone u szponiastych niż u grup zajmujących areały o mniejszej powierzchni. Antropogeniczne transformacje środowiska moga modyfikować te wskazówki, prowadzac do błędnych (maladaptatywnych) decyzji dotyczacych osiedlania się. Efektem takich decyzji może być obniżony sukces reprodukcyjny (HOLLANDER i współaut. 2011).

W ostatnich latach obserwuje się wzrost powierzchni upraw rzepaku, stanowiących rodzaj pułapki ekologicznej dla gniazdujacych ptaków szponiastych. Pomimo licznych cech siedliska optymalnego na poczatku sezonu lęgowego (w maju, szczególnie w latach z zimna wiosna, wysokość i zagęszczenie rzepaku nie różni się zbytnio od innych upraw; KOLEČEK i współaut. 2015) i dość wysokiej preferencji błotniaka łąkowego względem upraw rzepaku w Polsce (szczególnie w latach $z$ zimna wiosna), sukces lęgowy $\mathrm{w}$ tej uprawie jest bliski zera (Krupiński inf. ustne, Hałas obs. własne). Gęsta roślinność tworzy zimny mikroklimat przy powierzchni ziemi (ALPMANN 2006), a uboga pokrywa roślinna przy glebie nie stanowi warstwy izolacyjnej i utrudnia ogrzewanie jaj, szczególnie w czasie silnych opadów deszczu (Krupiński inf. ustna, Hałas obs. własne). Jest to ponadto najwcześniej koszona uprawa, co 
wiąże się $z$ dużym zagrożeniem dla gniazdujacych ptaków ze strony maszyn rolniczych (KOLEČEK i współaut. 2015).

Małe gospodarstwa otoczone półnaturalnymi pastwiskami i płatami roślinności nieuprawnej cechuja się wysoką wartościa przyrodnicza dla ptaków w intensywnym krajobrazie rolniczym, i charakteryzują się dużą różnorodnością gatunkową (DONALD i współaut. 2001, TRYJANOWSKI i współaut. 2011, Hiron i współaut. 2013). Załamanie populacji pójdźki (Athene noctua) w Europie Centralnej jest prawdopodobnie spowodowane likwidacja małych gospodarstw i odejściem od tradycyjnego pasterstwa, na skutek dążenia do uzyskania dużych, jednorodnych upraw (TSCHARNTKE i współaut. 2005, ŠÁlEK i współaut. 2013). Natomiast utrzymanie rozpowszechnionej gospodarki pasterskiej na Wegrzech jest przypuszczalnie przyczyna utrzymywania się wysokich zagęszczeń tego gatunku w tym kraju (ŠÁLEK i współaut. 2013).

Wraz $z$ intensyfikacją rolnictwa następuje konwersja gospodarstw w wyłacznie zbożowe lub hodowlane ( $z$ dużo wyższym poziomem intensywności użytkowania pastwisk), a heterogeniczny krajobraz rolniczy zostaje przekształcony w homogeniczne, wielkopowierzchniowe monokultury (NEWTON 2004). Siedliska kreowane przez te najbardziej intensywne systemy rolnicze nie sa zajmowane przez błotniaka łakowego, który preferuje uprawy mniejszych rozmiarów (POPRACH i współaut. 2013). Płaty siedlisk optymalnych staja się zbyt małe i odizolowane od głównych obszarów lęgowych błotniaka zbożowego (Circus cyaneus), co redukuje jakość siedlisk legowych i negatywnie odbija się na stanie populacji tego gatunku (WATSON i THIRGOOD 2001). Mozaika siedlisk w krajobrazie rolniczym istotna jest także dla innych gatunków o dużych areałach osobniczych, np. dropia (Otis tarda) (STOATE i współaut. 2009).

\section{WPŁYW INTENSYFIKACJI ROLNICTWA NA ZASOBY POKARMOWE}

Ubożenie zasobów pokarmowych to jeden $z$ poważniejszych skutków intensyfikacji rolnictwa (CARDADOR i współaut. 2012, 2014). W wielu regionach intensywnie użytkowany krajobraz rolniczy charakteryzuje się znacznie niższym bogactwem gatunkowym i biomasa bezkręgowców i kręgowców w porównaniu do siedlisk naturalnych, łak i ekstensywnych obszarów rolniczych (VICKERY i współaut. 2001, DI MAGGIO i współaut. 2016). Intensyfikacja rolnictwa w Kazachstanie redukuje liczebność susłów i myszoskoczków - głównych składników diety orła stepowego (Aquila nipalensis), kurhannika
(Buteo rufinus) i raroga (Falco cherrug) (SÁNCHEZ-ZAPATA i współaut. 2003). Ograniczenie zasobności łowisk jest także jedna $z$ głównych przyczyn regresu liczebności populacji błotniaka łakkowego i pustułeczki (Falco naumanni) (ARROYO i współaut. 2003, URSÚA i współaut. 2005). Zredukowana jest ponadto różnorodność gatunkowa zespołu ofiar. W intensywnych systemach rolniczych nornikowate osiagaja wyższe zagęszczenia niż inne małe gryzonie, co przekłada się na bardziej jednorodna dietę ptaków szponiastych (MILLÁN DE LA PEÑA i współaut. 2003, CARDADOR i współaut. 2012).

Zanikanie $\operatorname{mied} z$ i redukcja powierzchni zasiedlonych przez nieuprawne gatunki roślin skrajów pól uprawnych przyczynia się do zmniejszenia liczebności bezkręgowców, gryzoni i ptaków wróblowych krajobrazu rolniczego (TUCKer i HEATH 1994, PAIN i PIENKOWSKI 1997, GILlings i współaut. 2010). Heterogeniczny krajobraz rolniczy $z$ ugorami i miedzami jest kluczowy dla przetrwania kolonii i zachowania stabilnej populacji pustułeczki (URSÚA i współaut. 2005, GARCÍA i współaut. 2006). Zanik tych siedlisk skutkuje spadkiem liczebności tego gatunku. Sąsiedztwo zwierząt gospodarskich oraz ląk i pastwisk dostarcza ptakom szponiastym i sowom zróżnicowanych źródeł pokarmu w ciagu roku (HIRON i współaut. 2013). Zgodnie $z$ CHAMBERLAIN i współaut. (2000), specjalizacja gospodarstw w wyłącznie zbożowe lub hodowlane i upraszczanie rotacji upraw dodatkowo pogłębiają utratę różnorodności biologicznej (STOATE i współaut. 2009).

Modyfikacja praktyk rolniczych powoduje, że zasoby pokarmowe przyjmuja nieregularny, dynamiczny wzorzec rozmieszczenia, zwiąany $z$ rodzajem i częstotliwością prac agrotechnicznych (np. koszenie) (JOHST i współaut. 2001). Zmianie ulegaja także strategie lęgowe ptaków kolonijnych. Czajki, typowy gatunek półkolonijny, zaczynaja gniazdować w nielicznych skupiskach lub pojedynczo m. in. na skutek ubożenia zasobów pokarmowych (Kuczyński inf. ustna, Hałas obs. własne). Kukurydza, rzepak ani zboża ozime nie stanowia dogodnego siedliska lęgowego dla wielu potencjalnych ofiar ptaków szponiastych, np. skowronka (BRANDT i GLEMNITZ 2014, KOLEČEK i współaut. 2015). Szybki wzrost uprawy i jej zwarta struktura zmusza wiele ptaków do porzucenia gniazd, które staja się trudniej dostępne, a brak gęstej pokrywy roślinnej tuż przy ziemi uniemożliwia ukrycie gniazda przed drapieżnikami i nie sprzyja utrzymywaniu wysokiej różnorodności gatunkowej owadów (STOATE i współaut. 2009). Dlatego skowronki gniazdujące w uprawach zbóż zakładaja gniazda na ścieżkach technologicznych, co ułatwia 
ich wykrycie przez drapieżniki (KOLEČEK i współaut. 2015).

Stosowanie pestycydów redukuje liczebność bezkręgowców i małych kręgowców (VICKERY i współaut. 2001, STOATE i współaut. 2009). Wysokie dawki środków chemicznej ochrony roślin w uprawach kukurydzy skutecznie zmniejszaja bazę pokarmowa ptaków (tak roślinna jak i zwierzęca) (CARDADOR i MAÑOSA 2011, KOLEČEK i współaut. 2015). Oddziaływanie środków chemicznej ochrony roślin sięga również siedlisk graniczacych $z$ polami uprawnymi, szczególnie ich stref brzeżnych (PROSSER i współaut. 2016). Herbicydy moga redukować produktywność roślin (przekładając się na zmniejszenie liczebności zasiedlajacych je stawonogów) i niekorzystnie wpływać na gatunki nieuprawne, które stanowia pokarm bezkręgowców i roślinożernych kręgowców (PROsSER i współaut. 2016). Na przykład, PROSSER i współaut. (2016) wykazali, że na skrajach płatów, w strefie granicznej upraw i siedlisk sąsiadujących $\mathrm{Z}$ opryskiwanymi polami uprawnymi, obecność pluskwiaków Hemiptera, larw pilarzowatych Tenthredinidae, larw motyli Lepidoptera oraz stonkowatych Chrysomelidae była istotnie niższa (odpowiednio: $71 \%$ i $57 \%$ mniej) niż $w$ rejonach nie poddawanych opryskom. W granicach siedlisk przylegajacych do upraw nie poddawanych opryskom, obserwowana była także istotnie wyższa liczebność przedstawicieli np. pluskwiaków różnoskrzydłych Heteroptera, plewików Auchenorrhyncha, chrzaszczy Coleoptera, muchówek Diptera i pająków Araneae (PROSSER i współaut. 2016).

Ubożenie zasobów pokarmowych może przejawiać się również obniżoną dostępnością ofiar dla polujących ptaków szponiastych, pomimo ich wysokiej liczebności. W uprawach szybko dojrzewających, gęstniejaca w miarę postępu sezonu lęgowego pokrywa roślinna znacznie utrudnia wypatrzenie i schwytanie ofiary (np. ARLETTAz i współaut. 2010). Choć zagęszczenia gryzoni, np. nornika (Microtus sp.) w rzepaku często przewyższają zagęszczenia tych gatunków w innych uprawach (PANEK i HUŠEK 2014), moga być one trudno dostępne dla polujacych ptaków szponiastych ze względu na wysokość i zwarta strukturę roślinności (ARLETTAZ i współaut. 2010, CATRY i współaut. 2012, PANEK i HUŠEK 2014, KOLEČEK i współaut. 2015).

Redukcja powierzchni zasobnych żerowisk (zarówno w zakresie liczebności ofiar jak i ich dostępności) zmusza ptaki do poszukiwania pokarmu w dużej odległości od gniazd (POPRACH i współaut. 2013, COSTANTINI i współaut. 2014), co wiąże się ze wzrostem wydatków energetycznych dorosłych osobników oraz może negatywnie wpływać na kondycję młodych karmionych zbyt rzadko (Costantini i współaut. 2014). Pustułeczki zasiedlajace intensywny krajobraz rolniczy żeruja ponad $16 \mathrm{~km}$ od kolonii, podczas gdy w ekstensywnych agrocenozach ptaki oddalaja się na nie więcej niż $3 \mathrm{~km}$ (GARCÍA i współaut. 2006). Za główną przyczynę spadku liczebności tego gatunku uznaje się redukcję zasięgu i pogorszenie jakości żerowisk (ubożenie zasobów pokarmowych i niska dostępność ofiar) (PÉREZ i współaut. 2011). Prawdopodobieństwo przetrwania kolonii znajdujacych się w otoczeniu pastwisk, łąk i ekstensywnych upraw jest o 50\% wyższe niż kolonii zlokalizowanych w intensywnie użytkowanych obszarach rolniczych (DI MAGGIO i współaut. 2016). Gorsza kondycja piskląt pustułek (Falco tinnunculus) zasiedlajacych silnie przekształcony krajobraz rolniczy może być efektem gorszej opieki rodzicielskiej wskutek niższej dostępności ofiar (CostanTini i współaut. 2014) lub wynikać z przewagi mniejszych, mniej wartościowych ofiar (TELla i współaut. 1998). Ponadto, pustułki w tych regionach przystępuja do lęgów później niż ptaki zamieszkujące naturalne lub ekstensywnie użytkowane siedliska (Costantini i współaut. 2014). Zgodnie z ARLETTAZ i współaut. (2010), pisklęta płomykówek (Tyto alba) wychowywane w intensywnych obszarach rolniczych odznaczaja sie niższa masa ciała i mniej młodych dożywa do uzyskania zdolności do lotu.

Choć intensyfikacja rolnictwa negatywnie wpływa na jakość zarówno siedlisk gniazdowych, jak i żerowiskowych dla ptaków (NEWTON 2004, BUTLER i współaut. 2007, Douglas i współaut. 2010), okres żniw poprawia krótkookresowo dostępność ofiar dla ptaków szponiastych (PEGGIE i współaut. 2011, CATRY i współaut. 2014). Gryzonie i gniazda ptaków wróblowych pozostaja nieosłonięte, a bezkręgowce są wypłaszane

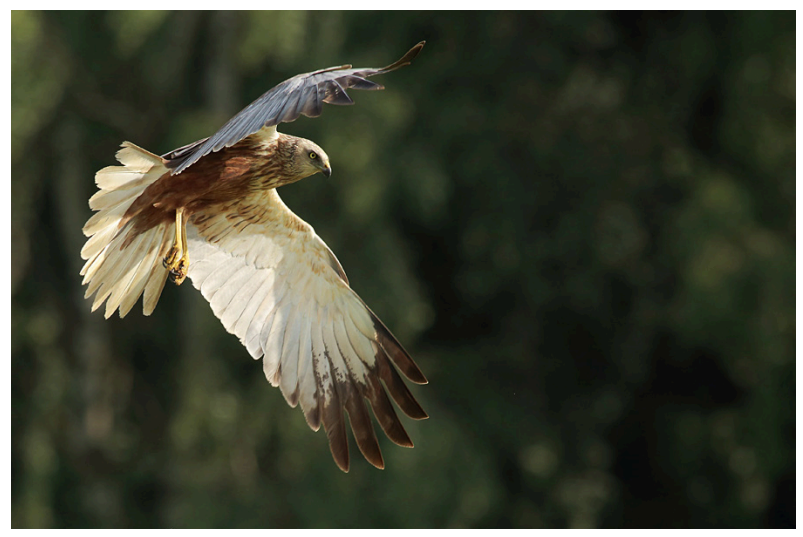

Ryc. 4. Samiec błotniaka stawowego (Fot. T. Książkiewicz). 


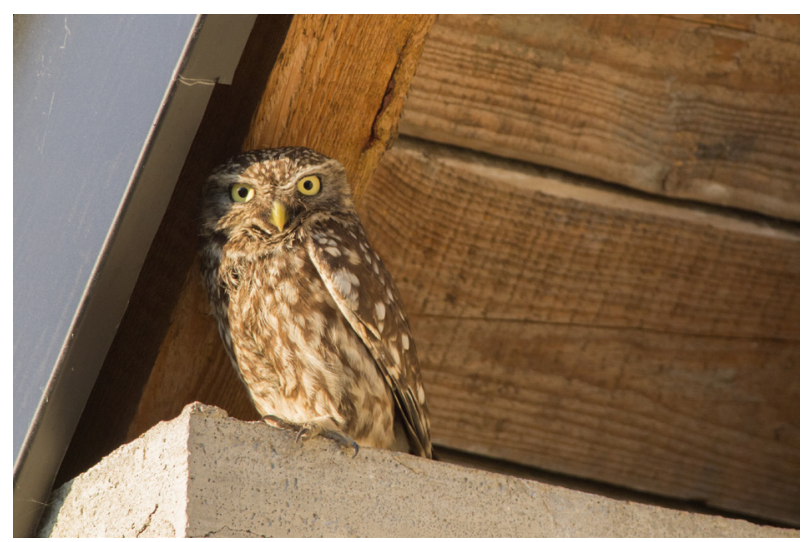

Ryc. 5. Pójdźka (fot. A. Łukijańczuk).

przez maszyny rolnicze (CATRY i współaut. 2014). Skoszone łaki i ścierniska chwilowo stają się preferowanym łowiskiem pustułeczki, błotniaka łakowego, błotniaka stawowego (Circus aeruginosus) (Ryc. 4) i pójdźki (Ryc. 5) (URSÚA i współaut. 2005, TOMÉ i współaut. 2011, CATRY i współaut. 2014). Podczas koszenia łak i żniw ginie jednak wiele owadów prostoskrzydłych (HUMBERT i współaut. 2010, CATRY i współaut. 2014), co przyczynia się znacznie do spadku zasobności tych siedlisk.

\section{ŚRODKI CHEMICZNEJ OCHRONY ROŚLIN A PTAKI SZPONIASTE}

Środki chemicznej ochrony roślin nie należa do podawanych w pierwszej kolejności zagrożeń dla ptaków szponiastych, jednak moga stanowić niedoceniony, pośredni czynnik ryzyka (np. MACEDO-SOUSA i współaut. 2009). Transfer pierwiastków i związków chemicznych w łańcuchu pokarmowym odbywa się na drodze bioakumulacji i biomagnifikacji w ciałach organizmów zajmujacych kolejne poziomy (TILMAN i współaut. 2001, MACEDO-Sousa i współaut. 2009). Stężenie substancji przyjętych wraz $z$ pokarmem (rośliny, bezkręgowce, gryzonie) rośnie w kolejnych szczeblach łańcucha pokarmowego (Costantini i współaut. 2014). Wówczas u organizmów zajmujacych szczytowe pozycje w łańcuchu pokarmowym może dojść do przekroczenia bezpiecznych stężeń toksyn, mimo że do środowiska dostaja się w stężeniach znacznie niższych (MACEDO-SOUSA i współaut. 2009).

Niektóre bezkręgowce wykazuja wysokie zdolności akumulacji metali ciężkich. MA (1982) i SCHEIFLER i współaut. (2006) stwierdzili transfer metali ciężkich $z$ gleby do organizmów rycyków (Limosa limosa) i kosów (Turdus merula) za pośrednictwem zjadanych bezkręgowców. Według GARCIA-HERAs i współaut. (2018) obecność DDT we krwi błotniaków czarnych (Circus maurus) występujacych w południowej Afryce wynika prawdopodobnie $z$ transferu tego środka poprzez ciało przepiórek (Coturnix coturnix), stanowiacych 25\% ich diety. DI MAGGIO i współaut. (2016) wykazali, że wysokie aplikacje biocydów w okresie wychowywania piskląt przez pustułeczki skutkowały dużą liczba zatrutych samic znalezionych martwych w gniazdach. GOLDSTEIN i współaut. (1999) oraz LóPEZ-LANÚs i współaut. (2008) podaja liczne przypadki zatrucia myszołowów preriowych (Buteo swainsoni) środkami chemicznej ochrony roślin, powszechnie stosowanymi do walki $z$ owadami w różnego rodzaju uprawach (lucernie, ziemniakach, pszenicy). Pestycydy moga także mieć negatywny wpływ na produkcje jaj i rozwój embrionów (NEWTON 2013). ROODBERGEN (2010) sugeruje możliwość występowania transferu niektórych metali niestanowiacych mikroelementów w organizmach żywych $z$ ciała samicy do jaj.

Stosowane w rolnictwie środki chemicznej ochrony roślin moga stanowić zagrożenie także dla ptaków szponiastych zasiedlajacych inne środowisko, jeśli ich pokarmem sa ptaki krajobrazu rolniczego (GARCIA-HERAS i współaut. 2018). Mimo niejasnego, ujawniajacego się dopiero $z$ upływem lat wpływu środków chemicznej ochrony roślin na organizmy zajmujace szczytowe pozycje w łańcuchach pokarmowych, środki te nadal sa powszechnie stosowane $\mathrm{w}$ rolnictwie. Ponadto, TILMAN i współaut. (2001) prognozują, że ilość stosowanych pestycydów wzrośnie ponaddwukrotnie do $2050 \mathrm{r}$.

\section{PTAKI SZPONIASTE W KRAJOBRAZIE ROLNICZYM}

Choć krajobraz rolniczy stanowi teren łowiecki dla wielu ptaków szponiastych, np. orzełka południowego (Aquila fasciata) (DI VITTORIO i współaut. 2012), niewiele gatunków znalazło tu siedliska legowe. Pierwszy przypadek gniazdowania błotniaka łąkowego w uprawach zbóż został opisany na początku XX w. w południowo-zachodniej Europie (FRIONNET 1925). Kolejne gatunki powoli wkraczały w agrocenozy w ciagu XX w., ale drastyczny wzrost liczby par gniazdujacych w krajobrazie rolniczym nastapił w ostatnich dekadach (ARROYO i współaut. 2002, POPRACH i współaut. 2013) i objął m. in. błotniaka stawowego i błotniaka zbożowego (DERUME i współaut. 2009, CARDADOR i MAÑOSA 2011). Jednocześnie, bardziej wrażliwe gatunki ptaków szponiastych, np. błotniak stepowy (Circus macrourus) nie sa obserwowane w krajobrazie rolniczym zachodniej Europy (TUCKER i HEATH 1994, SÁNCHEZ-ZAPATA i współaut. 2003). Do 1994 r. w krajobrazie 
rolniczym Eurazji nie stwierdzono gniazdowania orła cesarskiego (Aquila heliaca), orła stepowego, raroga (Falco cherrug), błotniaka stepowego i gadożera (Circaetus gallicus) (SÁNCHEZ-ZAPATA i współaut. 2003), gatunków rzadkich poza centrum zasięgu ich występowania w centralnej Azji.

Błotniak łakowy i błotniak stawowy sa gatunkami blisko spokrewnionymi, które w krajobrazie rolniczym znalazły zarówno żerowiska, jak i siedliska lęgowe. Obydwa gniazduja na ziemi, co stanowi dodatkowy czynnik ryzyka, i obu poświęcono znaczna liczbę prac. Jednak wplyw intensyfikacji rolnictwa na oba gatunki jest odmienny. Dlatego w niniejszej pracy postanowiłam szczegółowo omówić związek błotniaków $\mathrm{z}$ agrocenozami oraz wpływ przekształceń środowiska na ich populacje.

Błotniak lakowy stanowi, obok pustułeczki, przykład gatunku, który zaadaptował się do systemów rolniczych o niskiej intensywności (SÁNCHEZ-ZAPATA i współaut. 2003). Do skolonizowania krajobrazu rolniczego zmusił go zanik pierwotnych siedlisk lęgowych, tj. rozległych obszarów trawiastych, stepów i ekstensywnie użytkowanych łakk. Obecnie nawet $70 \%$ par błotniaka lakowego we Francji i 90\% w Hiszpanii i Portugalii gniazduje w uprawach zbóż (ARROYO i współaut. 2002). Gniazdowanie w uprawach, szczególnie zbóż ozimych, naraża gatunek na wysoki odsetek strat w lęgach (60-90\%) $\mathrm{w}$ czasie prac agrotechnicznych (MILLON i współaut. 2002). Do zachowania populacji przynajmniej $\mathrm{w}$ aktualnym stanie liczebnym sukces lęgowy powinien wynosić 2 młode na parę (np. ARROYO i współaut. 2002), jednak pary gniazdujace $\mathrm{w}$ krajobrazie rolniczym osiagaja sukces reprodukcyjny na poziomie znacznie niższym (MiLlon i współaut. 2002, SANTANGELI i współaut. 2015). W Polsce sukces lęgowy odnosi mniej niż 20\% spośród par, których gniazda nie były objęte ochrona czynna, a produktywność nie osiaga nawet 1 młodego na parę (Hałas i Krupiński dane niepubl.). Odpowiednio wysoka produktywność lęgów osiagana jest jedynie przez pary gniazdujace w siedliskach półnaturalnych, jednak stanowia one mniejszość (SANTANGELI i współaut. 2014).

Na obszarach, gdzie nadal dominuja siedliska naturalne $i$ półnaturalne, gatunek ten nie gniazduje w uprawach zbóż i cechuje się wyższym sukcesem lęgowym i wielkością lęgu (Millon i współaut. 2002, KoKS i współaut. 2007). To sugeruje, że krajobraz rolniczy stanowi środowisko zastępcze, suboptymalne, które nie jest preferowane przy dużej dostępności siedlisk pierwotnych, tj. ekstensywnie użytkowanych lakk, obszarów porośniętych roślinnością ruderalna, np. po- krzywami, młodych, niewysokich zarośli. Postępujące ubożenie zasobów pokarmowych i mniejsza dostępność pokarmu przechylaja szalę na niekorzyść tego gatunku (ARROYO i współaut. 2002). Dlatego konieczne jest podejmowanie czynnej ochrony lęgów, która odbywa się przez grodzenie gniazd. Działanie to ma na celu ochronę jaj i piskląt przed drapieżnikami naziemnymi i pracami agrotechnicznymi. We Francji brak czynnej ochrony powoduje ograniczenie produktywności populacji o 50\% (SANTANGELI i współaut. 2015), a w Polsce trzykrotnie niższy sukces lęgowy w stosunku do populacji objętej ochrona (Hałas obs. własne).

Błotniak łakkowy jest przykładem gatunku, w przypadku ochrony którego wkrótce może dojść do sytuacji patowej. Prowadzenie działań z zakresu czynnej ochrony gniazd umożliwia osiagnięcie odpowiednio wysokiego sukcesu lęgowego i przetrwanie populacji $\mathrm{w}$ krajobrazie rolniczym. Wiąze się to jednak $z$ dużymi nakładami finansowymi. W dłuższej perspektywie działania te moga doprowadzić do pułapki konserwatorskiej (TORRES-OROZCO i współaut. 2016). Sztucznie (przez ochronę gniazd) utrzymywana populacja będzie osiągała coraz wyższa liczebność, a jej ochrona będzie generowała coraz wyższe koszty. W pewnym momencie wzrost nakładów finansowych na czynną ochronę gatunku przestanie być opłacalny, a fundusze się skończa. Wówczas może dojść do regresu populacji lub lokalnych wyginięć. Wydaje się, że już teraz należałoby rozpoczać prace nad nowelizacja WPR i systemu gospodarki rolnej oraz rozpocząc prace nad projektami zachowania i ochrony naturalnych siedlisk, pierwotnych miejsc gniazdowania nie tylko błotniaka łakowego, ale i innych gatunków, które aktualnie zasiedlaja krajobraz rolniczy.

$Z$ drugiej strony, intensywny krajobraz rolniczy stał się dogodnym siedliskiem zastępczym dla zanikajacych mokradel, pierwotnie zajmowanych przez błotniaka stawowego. Przyczyniło sie to do znacznego wzrostu liczebności i ekspansji tego gatunku (CARDADOR i współaut. 2011). Jako jedyny spośród ptaków szponiastych zdaje się on korzystać $z$ intensyfikacji rolnictwa (STERNALSKI i współaut. 2013, CARDADOR i współaut. 2014). Dodatkowo, elastyczne korzystanie $z$ różnych upraw jako siedlisk łowieckich może sprzyjać mniejszej wrażliwości błotniaka stawowego na transformację rolnictwa (CARDADOR i współaut. 2014).

Pary gniazdujace $\mathrm{w}$ intensywnym krajobrazie rolniczym nie wykazuja niższego sukcesu lęgowego niż pary zasiedlające bardziej naturalne siedliska (CARDADOR i współaut. 2011), a w latach wysokiej liczebności norników produktywność populacji jest wyższa 
(STERNALSKI i współaut. 2013). W intensywnych systemach rolniczych zbiorniki irygacyjne zastapiły błotniakowi stawowemu jego naturalne siedliska lęgowe, a sassiadujące uprawy roślin zielnych - łowiska (CARDADOR i MAÑOSA 2011, CARDADOR i współaut. 2014). Osobniki zasiedlajace intensywny krajobraz rolniczy zdaja się mieć mniejsze areały osobnicze niż ptaki żyjace w bardziej ekstensywnych systemach (CARDADOR i współaut. 2011), co może być spowodowane wyższą liczebnością małych ssaków (CARDADOR i współaut. 2012). Przykładowo, uprawy roślin zielnych w dolinie rzeki Ebro zdaja się utrzymywać wyższe zagęszczenia małych ssaków niż bardziej ekstensywne uprawy (CARDADOR i współaut. 2011). Błotniak stawowy może ponadto korzystać $z$ niskiej konkurencji ze strony innych ptaków szponiastych (CARDADOR i współaut. 2014), jednocześnie będąc drapieżnikiem np. błotniaka łąkowego (Krupiński inf. ustna, Hałas obs. własne). Wiele analiz wskazało na wysoka dostępność ofiar dla błotniaka stawowego $\mathrm{w}$ intensywnym krajobrazie rolniczym. Przypuszczalnie jako największy spośród ptaków szponiastych, które zasiedliły agrocenozy, poluje na ofiary większe, łatwiej widoczne i dostępne, niekiedy także na pisklęta innych szponiastych (CARDADOR i współaut. 2011, 2012).

Choć gniazdowanie w agrocenozach wydaje się być korzystne dla błotniaka stawowego, w dalszym horyzoncie czasowym może stwarzać trudności (STERNALSKI i współaut. 2013). Filopatria (tendencja do osiedlania się w pobliżu miejsca pochodzenia), zanikanie naturalnych siedlisk i wysoki sukces legowy w agrocenozach, moga powodować, że liczba par gniazdujacych w krajobrazie rolniczym będzie wzrastać, co może mieć negatywne konsekwencje dla populacji, jeśli utrzyma się tendencja do coraz wcześniejszego terminu żniw (CHAMBERLAIN i współaut. 2000). Jeśli populacje gniazdujacee w uprawach zbóż wpisują się w dynamikę źródło-ujście (stanowiac populacje ujściowe), zanik populacji źródłowych, bardziej produktywnych, zasilajacych populacje agrocenoz może doprowadzić do załamania całej populacji i drastycznego spadku liczebności gatunku (STERNALSKI i współaut. 2013). Gniazdowanie w intensywnym krajobrazie rolniczym wiąże się $z$ ekspozycja na środki chemicznej ochrony roślin, co może nieść niekorzystne konsekwencje fizjologiczne i oddziaływać długoterminowo na dynamikę populacji w tych obszarach (MAÑosA i współaut. 2001). Wpływ intensyfikacji rolnictwa na produktywność, przeżywalność czy kondycję błotniaków stawowych między kolejnymi latami i sezonami rozrodczymi wciąż pozostaje nieznany (CARDADOR i współaut. 2012), a efekty mogą ujawnić się w przyszłości. Ponadto, Moreno-Mateos i współaut. (2009) definiują zjawisko „welcome opportunity” jako tymczasowa pozytywna reakcję liczbowa gatunków na nowe środowisko, która może odwrócić się z biegiem lat. Populacje moga wydawać się stabilne dopóki sa zasilane osobnikami $z$ populacji źródłowych, a po zamknięciu dopływu rekrutów z zewnątrz moga ulec regresowi lub całkowicie zaniknacć (MORENo-MATEOS i współaut. 2009). Dlatego nie powinny być traktowane jako mogace zastapić populacje zamieszkujące siedliska pierwotne, szczególnie dopóki nie zostana poznane mechanizmy długoterminowej odpowiedzi gatunków na przekształcenia środowiska przyrodniczego.

\section{PODSUMOWANIE}

Intensyfikacja rolnictwa uznawana jest za jedno $z$ najpoważniejszych zagrożeń antropogenicznych dla różnorodności biologicznej, a skalę jej oddziaływania porównuje się do globalnego wylesiania i zmian klimatu (SAUNDERS i współaut. 1991, DONALD i współaut. 2001). Dla większości gatunków ptaków postępujace zmiany w systemie gospodarki rolnej sa bariera i przyczyniaja się do zmniejszania liczebności populacji i zasięgu występowania, np. błotniak łąkowy, pustułeczka i większość ptaków siewkowych (Tella i współaut. 1998, DONALD i współaut. 2001, Di ViTTORIO i współaut. 2012). Jeśli nie zmienia się aktualnie obserwowane trendy w rolnictwie, nie uda się powstrzymać silnych spadków liczebności populacji wielu gatunków ptaków, a prawdopodobne jest nawet nasilenie tych niekorzystnych procesów (PRINCÉ i współaut. 2015). W dłuższym horyzoncie czasowym intensyfikacja rolnictwa może prowadzić do homogenizacji biotycznej - niespotykanej dotąd formy zmian globalnych (RICCIARDI 2007) i najpoważniejszej formy wyniszczenia biologicznego w skali światowej (OldEN i współaut. 2004). Prognozuje się, że do 2050 r. produkcja rolna ulegnie podwojeniu (TILMAN 1999), a postępujaca intensyfikacja rolnictwa i degradacja naturalnych ekosystemów zwiększy liczbę gatunków globalnie zagrożonych wyginięciem (TILMAN i współaut. 2001).

Krajobraz rolniczy może cechować się dużą heterogenicznością siedlisk, zróżnicowaną struktura i wysoka różnorodnością biologiczna tylko jeśli gospodarka rolna realizowana jest w sposób ekstensywny (COSTANTINI i współaut. 2014, STOATE i współaut. 2009). Wówczas staje się optymalnym środowiskiem życia dla ptaków siedlisk ląkowych i stepowych (MACEDo-SousA i współaut. 2009). Modyfikacja polityki rolnej i zatrzymanie inten- 
syfikacji praktyk rolniczych wydają się być niezbędne dla zachowania populacji gatunków rzadkich, zmniejszających swoja liczebność i powstrzymania utraty różnorodności biologicznej (np. DI VITTORIO i współaut. 2012). Poznanie zwiazku sukcesu lęgowego i produktywności populacji $z$ charakterystyka siedliskową może umożliwić przewidywanie konsekwencji zmian w sposobie użytkowania gruntów dla dynamiki i stanu populacji gatunków chronionych i zagrożonych, zasiedlajacych podlegajacy silnym zmianom krajobraz rolniczy (STERNALSKI i współaut. 2013).

\section{Streszczenie}

Agrocenozy moga charakteryzować się wysoka wartościa przyrodnicza, będąc miejscem występowania rzadkich i chronionych gatunków. Postępująca intensyfikacja rolnictwa przyczyniła się jednak do pogorszenia jakości siedlisk w krajobrazie rolniczym, drastycznych spadków liczebności populacji wielu gatunków ptaków i zubożenia różnorodności biologicznej. W niniejszym artykule przedstawiono mechanizmy oddziaływania intensyfikacji rolnictwa na ptaki szponiaste, które utrzymuja rozległe areały osobnicze i zajmuja szczytowe pozycje w łańcuchach troficznych. Wplyw intensyfikacji rolnictwa na ptaki podzielono na: bezpośredni, tj. fizyczne niszczenie miejsc rozrodu, prowadzace do śmierci młodych i osobników dorosłych; oraz pośredni, obejmujacy presję na siedliska i zasoby pokarmowe oraz oddziaływanie pestycydów na ptaki wskutek bioakumulacji. Następnie scharakteryzowano proces zasiedlenia agrocenoz przez dwa gatunki modelowe: błotniaka lakowego Circus pygargus i błotniaka stawowego Circus aeruginosus. Wiele gatunków ptaków szponiastych, np. błotniak łakowy, po wkroczeniu w krajobraz rolniczy zaczęło zmniejszać liczebność. Inne, np. błotniak stawowy, zaadaptowały się do specyfiki funkcjonowania agrocenoz. Jednakże, brak widocznego, negatywnego wpływu intensyfikacji rolnictwa na ptaki może być tymczasowy, spowodowany np. obecnościa populacji źródłowych, zasilających populacje ujściowe zasiedlające krajobraz rolniczy. W dłuższym horyzoncie czasowym intensyfikacja rolnictwa może prowadzić do dalszej homogenizacji biotycznej w krajobrazie rolniczym.

\section{LITERATURA}

AlPMANN L., 2006. Raps: Anbau und Verwertung einer Kultur mit Perspektive. Landwirtschaftsverlag, Münster.

ARLETTAZ R., KRÄHENBÜHL M., Almasi B., Roulin A., ScHAUB M., 2010. Wildflower areas within revitalized agricultural matrices boost small mammal populations but not breeding barn owls. J. Ornithol. 151, 553-564.

ARROYO B., GARCIA J. T., BRETAGNOLlE V., 2002. Conservation of the Montagu's harrier (Circus pygargus) in agricultural areas. Animal Conserv. 5, 283-290.

ARRoyo B. E., BREtagnolle V., Garcia J. T., 2003. Land use, agricultural practices and conservation of Montagu's Harrier. [W:] Birds of prey in a changing environment. THOMPSON D. B. A., RedPATH S. M., FIELding A. H., Marquiss M., Galbraith C. A. (red.). The Stationery Office, Edinburgh, 449-463.

BAŃSKI J., 2009. Historia rozwoju gospodarki rol nej na ziemiach polskich. [W:] GóRKA Z., ZBOROWSKI A. (red.). Człowiek $i$ rolnictwo. Instytut
Geografii i Gospodarki Przestrzennej, Uniwersytet Jagielloński, Kraków, 33-45.

BÁLDI A., BATÁRY P., 2011. Spatial heterogeneity and farmland birds: different perspectives in Western and Eastern Europe. Ibis, 153, 875876.

BIRDLIFE INTERNATIONAL, 2004. Birds in Europe: population estimates, trends and conservation status. BirdLife International Series 12, Cambridge, UK.

BLAXTER K., ROBERTSON N., 1995. From death to plenty: The second agricultural revolution. Cambridge University Press, Cambridge.

BRANDT K., GLEMNITZ M., 2014. Assessing the regional impacts of increased energy maize cultivation on farmland birds. Environ. Monitor. Asses. 186, 679-697.

Buckingham D. L., Giovannini P., Peach W. J., 2015. Manipulating grass silage management to boost reproductive output of a ground-nesting farmland bird. Agricult. Ecosyst. Environ. 208, 21-28.

BUtLER S. J., ViCKeRY J. A., NORRIS K., 2007. Farmland biodiversity and the footprint of agriculture. Science 315, 381-384.

Butler S. J., BOCCACCIO L., GREGORY R., VORISEK P., NORRIS K., 2010. Quantifying the impact of land-use change to European farmland bird populations. Agricult. Ecosyst. Environ. 137, 348-357.

CARDADOR L., MAÑOSA S., 2011. Foraging habitat use and selection of western marsh harriers (Circus aeruginosus) in intensive agricultural landscapes. J. Raptor Res. 45, 168-173.

CARDADOR L., CARRETE M., MAÑ́OSA S., 2011. Can intensive agricultural landscapes favour some raptor species? The Marsh harrier in north-eastern Spain. Animal Conserv. 14, 382-390.

CARDADOR L., Planas E., VARea A., Mañosa S., 2012. Feeding behaviour and diet composition of the Marsh Harrier Circus aeruginosus in agricultural landscapes. Bird Study, 59, 228235.

Cardador L., Carrete M., Mañosa S., 2014. Factors affecting the expansion success of bird populations in human-transformed environments: the case of the Marsh Harrier Circus aeruginosus in the Ebro Valley. Catal. J. Ornithol. 30, 90-101.

Carrete M., Tella J. L., Blanco G., BertellotTI M., 2009. Effects of habitat degradation on the abundance, richness and diversity of raptors across Neotropical biomes. Biol. Conserv. $142,2002-2011$.

Catry I., Amano T., Franco A. M. A., Sutherland W. J., 2012. Influence of spatial and temporal dynamics of agricultural practices on the Lesser Kestrel. Journal of Applied Ecology, 49, 99-108

CATRY I., FRANCO A. M. A., MOREIRA F., 2014. Easy but ephemeral food: exploring the tradeoffs of agricultural practices in the foraging decisions of lesser kestrels on farmland. Bird Study 1, 1-10.

Chamberlain D. E., Siriwardena G. M., 2000. The effects of agricultural intensification on skylarks Alauda arvensis: evidence from monitoring studies in Great Britain. Environ. Rev. $8,95-113$

Chamberlain D. E., Fuller R. J., Bunce R. G. H., DUCKWORTH J. C., SHRUBB M., 2000. Changes in the abundance of farmland birds in relation to the timing of agricultural intensification in England and Wales. J. Appl. Ecol. 37, 771-788. 
Costantini D., Dell'omo G., La Fata I., CASAgranDE S., 2014. Reproductive performance of Eurasian Kestrel Falco tinnunculusin an agricultural landscape with a mosaic of land uses. Ibis 156, 768-776

CSÁKI C., JÁMBOR A., 2013. The impact of EU accession: lessons from the agriculture of the new member states. Post-Comm. Econom. 25, 325-342.

Derume M., Guyon J., Bataille B., 2009. L'estivage des Busards des roseaux (Circus aeruginosus), saint-martin (Cyrcus cyaneus) et cendrés (Circus pygargus) dans les plaines agricoles de Wallonie: premières estimations. Aves 46, 49-56.

Di Maggio R., Campobello D., Tavecchia G., Sará M., 2016. Habitat and density-dependent demography of a colonial raptor in Mediterranean agro-ecosystems. Biol. Conserv. 193, 116-23.

Di VitTORIO M., MAURIZIO S., LÓPEZ-LóPEZ P., 2012. Habitat preferences of Bonelli's Eagles Aquila fasciata in Sicily. Bird Study 59, 207 217

Donald P. F., GReen R. E., Heath M. F., 2001. Agricultural intensification and the collapse of Europe's farmland bird populations. Proc. Royal Soc. B Biol. Sci. 268, 25-29.

DOUGLAS D. J. T., VICKERY J. A., BENTON T. G., 2010. Variation in arthropod abundance in barley under varying sowing regimes. Agricult. Ecosyst. Environ. 135, 127-131.

FOley J. A., DEFries R., ASNER G. P., BARFORD C., Bonan G. i współaut., 2005. Global consequences of land use. Science 309, 570-574.

FRIONNET C., 1925. Les oiseaux de la HauteMarne. Bulletin de la Societe des Sciences Naturelles de Haute-Marne (Chaumont).

García J. T., Morales M. B., Martínez J., IgleSias L., García De La Morena E., SuÁrez F., VIÑUELA J., 2006. Foraging activity and use of space by lesser kestrel Falco naumanni in relation to agrarian management in central Spain. Bird Conserv. Internat. 16, 83-95.

Garcia-Heras M.-S., ARroyo B., SimMons R. E., CAMARERO P. R., MATEO R., MOUgeot F., 2018. Blood concentrations of PCBs and DDTs in an avian predator endemic to southern $A f-$ rica: Associations with habitat, electrical transformers and diet. Environ. Pollut. 232, 440449.

Gillings S., Henderson I. G., MorRis A. J., VicKERY J. A., 2010. Assessing the implications of the loss of set-aside for farmland birds. Ibis $152,713-723$.

Gillis H., Gauffre B., HuOt R., Bretagnolle V., 2012. Vegetation height and egg coloration differentially affect predation rate and overheating risk: an experimental test mimicking a ground-nesting bird. Canad. J. Zool. 90, 694703.

GOLdSTEIN M. I., LACHER T. E., WOODBRIDGE B., BECHARD M. J., CANAVElli S. B., ZaCCAGNiNI M. E., COBB G. P., ScOllon E. J., TRIBOLET R., HOOPER M. J., 1999. Monocrotophos-induced mass mortality of Swainson's hawks in Argentina, 1995-96. Ecotoxicology 8, 201214.

GonzÁleZ-Estébanez F. J., García-TEuero S., MATEO-TOMÁS P., OlEA P. P., 2011. Effects of irrigation and landscape heterogeneity on butterfly diversity in Mediterranean farmlands. Agricult. Ecosyst. Environ. 144, 262-270.

Green R. E., CoRnell S. J., ScharlemanN J. P. W., BALMFORD A., 2005. Farming and the fate of wild nature. Science 307, 550-555.
Gregory R. D., VAN Strien A., VóRísek P., MeyLING A. W. G., Noble D. G., Foppen R. P. B., GiBBONS D. W., 2005. Developing indicators for European birds. Philosoph. Transact. Royal Soc. B Biol. Sci. 360, 269-288.

GuerRero I., Morales M. B., ÓNATE J. J., AAVIK T., BENGTSSON J. i współaut., 2011. Taxonomic and functional diversity of farmland bird communities across Europe: effects of biogeography and agricultural intensification. Biodivers. Conservat. 20, 3663-3681.

Gus, 2012. Statistical Yearbook of Agriculture 2012. Central Statistical Office, Warsaw.

Henle K., Alard D., Clitherow J., COBB P., FirBANK L. i współaut., 2008. Identifying and managing the conflicts between agriculture and biodiversity conservation in Europe - a review. Agricult. Ecosyst. Environ. 124, 60-71.

Hiron M., BERG L., EGGERS S., PÄRT T., 2013. Are farmsteads over-looked biodiversity hotspots in intensive agricultural ecosystems? Biol. Conservat. 159, 332-342.

HOLlander F. A., VAN DYCK H., MARTin G. S., TITEUX N., 2011. Maladaptive habitat selection of a migratory passerine bird in a human-modified landscape. PLoS One, 6, e25703.

HumberT J. Y., GHazoul J., RichneR N., WALTER T., 2010. Hay harvesting causes high orthopteran mortality. Agricult. Ecosyst. Environ. 139, 522-527.

JOHST K., BRANDL R., PFEIFER R., 2001. Foraging in a patchy and dynamic landscape: human land us and the White stork. Ecol. Applic. 11, 60-69.

Kleijn D., Kohler F., BÁldi A., BatÁRy P., ConCEPCION E. D. i współaut., 2009. On the relationship between farmland biodiversity and land-use intensity in Europe. Proc. Royal Soc. London B Biol. Sci. 276, 903-909.

KoKS B. J., TRIERWEILER C., VISSER E. G., DIJKSTRA C., KOMDEUR J., 2007. Do voles make agricultural habitat attractive to Montagu's Harrier Circus pygargus? Ibis 149, 575-586.

KOLEČEK J., REIF J., WEIDINGER K., 2015. The abundance of a farmland specialist bird, the skylark, in three European regions with contrasting agricultural management. Agricult. Ecosyst. Environ. 212, 30-37.

KREBS J. R., WILSON J. D., BRADBURY R. B., SiRIWARDENA G. M., 1999. The second Silent Spring? Nature 400, 611-612.

LAIOLO P., TELLA J. L., 2006. Fate of unproductive and unattractive habitats: recent changes in Iberian steppes and their effects on endangered avifauna. Environ. Conserv. 33, 223232.

LóPez-Lanús B., Grilli P., COCONIER E., Di GiaCOMO A., BANCHS R., 2008. Categorización de las aves de la Argentina según su estado de conservación. Informe de Aves Argentinas/ AOP y Secretaría de Ambiente y Desarrollo Sustentable.

López- López P., de La Puente J., Mellone U., BERMEJO A., URIOS V., 2016. Spatial ecology and habitat use of adult Booted Eagles (Aquila pennata) during the breeding season: implications for conservation. J. Ornithol. 157, 981-993.

MA W. C., 1982. Biomonitoring of soil pollution: Ecotoxicological studies of the effect of soilborne metals on lumbricid earthworms. Annual ReporT, Research Institute for Nature Management, Arnhem, The Netherlands.

MACEDO-SOUSA J. A., SOARES A. M. V. M., TARAZONA J. V., 2009. A conceptual model forassessing risks in a Mediterranean Natura 2000 
Network site. Sci. Total Environ. 407, 12241231.

Mañosa S., Mateo R., GuitaRT R., 2001. A review of the effects of agricultural and industrial contamination on the Ebro delta biota and wildlife. Environ. Monitor. Assess. 71, 187205.

MARZLUFF J. M., 2001 Worldwide urbanization and its effects on birds. [W:] Avian ecology and conservation in an urbanizing world. MARZlufF J. M., BOWMAN R., DONELlY R. E. (red.). Kluwer, Boston, 19-49.

Millán de la Peña N., Butet A., Delettre Y., Paillat G., Morant P., LE Du L., Burel F., 2003. Response of the small mammal community to changes in western French agricultural landscapes. Lands. Ecol. 18, 265-278.

Millon A., BourRiouX J. L., Riols C., BRETAGNOLLE V., 2002. Comparative breeding biology of Hen Harrier and Montagu's Harrier: an 8-year study in north-eastern France. Ibis 144, 94105.

MORELLI F., JERZAK L., TRYJANOWSKI P., 2014. Birds as useful indicators of high nature value (HNV) farmland in Central Italy. Ecol. Indicat. 38, 236-242.

Moreno-Mateos D., Pedrocchi C., Comín F. A., 2009. Avian communities' preferences in recently created agricultural wetlands in irrigated landscapes of semi-arid areas. Biodivers. Conserv. 18, 811-828.

NEWTON I., 2004. The recent declines of farmland bird populations in Britain: an appraisal of causal factors and conservation actions. Ibis 146, 579-600.

NEWTON I., 2013. Organochlorine pesticides and birds. Brit. Birds 106, 189-205.

Olden J. D., POFF N. L., DOUGlas M. R., DougLAS M. E., FAUSCH K. D., 2004. Ecological and evolutionary consequences of biotic homogenization. Trends Ecol. Evol. 19, 18-24.

Overmars K. P., Schulp C. J. E., Alkemade R., Verburg P. H., Temme A. J. A. M., Omtzigt N., SChAminÉE J. H. J., 2014. Developing a methodology for a species-based and spatially explicit indicator for biodiversity on agricultural land in the EU. Ecol. Indicat. 37, 186-198.

PAIN D. J., PIENKOWsKI M. W., 1997. Farming and birds in Europe. The common agricultural policy and its implications for bird conservation. Academic Press, London.

PANEK M., HUSEK J., 2014. The effect of oilseed rape occurrence on main prey abundance and breeding success of the common buzzard $\mathrm{Bu}$ teo buteo. Bird Study 61, 457-464.

Peggie C. T., Garratt C. M., WhitTingham M. J., 2011. Creating ephemeral resources: how long do the beneficial effects of grass cutting last for birds? Bird Study 58, 390-398.

Pérez I., NOGUera J. C., MíngueZ E., 2011. Is there enough habitat for reintroduced populations of the Lesser Kestrel? A case study in eastern Spain. Bird Conserv. Internat. 21, 228-239.

PoPrach K., MACHAR I., VRBKová J., 2013. Population trend, distribution and habitat requirements of the Montagu's Harrier (Circus pygargus) in central Moravia (Czech Republic). Sylvia 49, 111-134.

PRINCÉ K., LORRILliÈre R., BARBET-MASSIN M., LÉGER F., JIGUET F., 2015. Forecasting the Effects of Land Use Scenarios on Farmland Birds Reveal a Potential Mitigation of Climate Change Impacts. PLoS One, 10, e0117850.

PROSSER R. S., ANDERSON J. C., HANSON M. L. SOlOMON K. R., Sibley P. K., 2016. Indirect effects of herbicides on biota in terrestrial edge-of-field habitats: a critical review of the literature. Agricult. Ecosyst. Environ. 232, 5972 .

RICCIARDI A., 2007. Are Modern Biological Invasions an Unprecedented Form of Global Change? Conserv. Biol. 21, 329-336.

RoOdBERGen M., 2010. Population dynamics of black-tailed godwits in the light of heavy metal pollution. Groningen: s.n.

SANDERSON F. J., KucharZ M., Jobda M., DONALD P. F., 2013. Impacts of agricultural intensification and abandonment on farmland birds in Poland following EU accession. Agricult. Ecosyst. Environ. 168, 16-24.

SÁNCHEZ-ZAPATA J. A., CARRETE M., GRAVIlOV A., SKlyARENKO S., CEBAllos O., DONÁZAR J. A., HIRALDO F., 2003. Land use changes and raptor conservation in steppe habitats of eastern Kazakhstan. Biol. Conserv. 111, 71-77.

SANTANGEli A., Di Minin E., ARROYO B., 2014. Bridging the research implementation gap identifying cost-effective protection measures for Montagu's harrier nests in Spanish farmlands. Biol. Conserv. 177, 126-133.

SANTANGEl A., ARROYO B., Millon A., BRETAGNOLLE V., 2015. Identifying effective actions to guide volunteer-based and nationwide conservation efforts for a ground-nesting farmland bird. J. Appl. Ecol. 52, 1082-1091.

SAunders D. A., HoBbS R. J., MARgules C. R., 1991. Biological consequences of ecosystem fragmentation: a review. Conserv. Biol. 5, 1832.

ŠÁleK M., Chrenková M., Kipson M., 2013. High population density of little owl (Athene noctua) in hortobagy national park, Hungary, Central Europe. Polish J. Ecol. 61, 165-169.

SCHEIFLER R., COEURDASSIER M., MORILHAT C., BERNARD N., FAIVRE B., FlicoteauX P., GIRAudoux P., NOËL M., PiotTe P., ReIFFEL D., DE VAUfleUry A., BADOT P.-M., 2006. Lead concentrations in feathers and blood of common blackbirds (Turdus merula) and in earthworms inhabiting unpolluted and moderately polluted urban areas. Sci. Total Environ. 371, 197-205.

SCIERCIU S. SS., 2011. Socioeconomic and environmental impacts on agriculture in the New Europe: Post-communist transition and accession to the European Union (Routledge studies in ecological economics). Taylor \& Francis e-Library, New York.

Sergio F., Caro T., Brown D., Clucas B., HuntER J., KeTCHUM J., MCHUGH K., HiRALdo F., 2008. Top predators as conservation tools: ecological rationale, assumptions, and efficacy. Ann. Rev. Ecol. Evol. Systemat. 39, 1-19.

STERNALSKI A., BlANC J. F., AUGIRON S., ROCHETEAU V., BRETAGnolle V., 2013. Comparative breeding performance of marsh harriers Circus aeruginosus along a gradient of land-use intensification and implications for population management. Ibis 155 , 55-67.

Stoate C., BÁldi A., Beja P., BoAtman N. D., HERZON I., VAN DOORN A.,' DE SNOO G. R., RAKOSY L., RAMWELL C., 2009. Ecological impacts of early 21st century agricultural change in Europe - A review. J. Environ. Manage. $91,22-46$

Storkey J., Meyer S., Still K. S., Leuschner C., 2012. The impact of agricultural intensification and land-use change on the European arable flora. Proc. Royal Soc. B Biol. Sci. 279, 1421-1429. 
Sutcliffe L. M. E., BATÁRY P., KoRMANN U., BÁlD A., DiCKS L. V. i współaut., 2015. Harnessing the biodiversity value of Central and Eastern European farmland. Divers Distribut. 21, 722730.

Tella J. L., Forero M. G., Hiraldo F., Donázar J. A., 1998. Conflicts between lesser kestrel conservation and European agricultural policies as identified by habitat use analyses. Conserv. Biol. 12, 593-604.

TEws J., BERT D. G., Mineau P., 2013. Estimated mortality of selected migratory bird species from mowing and other mechanical operations in Canadian agriculture. Avian Conserv. Ecol. $8,8$.

Tilman D., 1999. Global environmental impacts of agricultural expansion: the need for sustainable and efficient practices. Proc. Natl. Acad. Sci. USA 96, 5995-6000.

Tilman D., FARGione J., WoifF B., Antonio C. D., DoBson A. i współaut., 2001. Forecasting agriculturally driven global environmental change. Science 292, 281-284.

Tomé R., Dias M. P., Chumbinho A. C., Bloise C., 2011. Influence of perch height and vegetation structure on the foraging behaviour of Little Owls Athene noctua: how to achieve the same success in two distinct habitats. Ardea 99, 17-26.

Torres-Orozco D., Arroyo B., Pomarol M., SANTANGELI A., 2016. From a conservation trap to a conservation solution: lessons from an intensively managed Montagu's harrier population. Animal Conserv. 19, 436-443.

TRIERWEILER C., KoKS B. J., 2009. Montagu's Harrier Circus pygargus. [W:] Living on the edge:
Wetlands and birds in a changing Sahel. ZWARTS L., BIJLSMA R. G., VAN DER KAMP J., WYMENGA E. (red.). KNNV Publishing, Zeist, The Netherlands, 173-202.

TRYJANOWSKI P., HARTEL T., BÁldi A., SZYMÁNSKI P., TOBOlKA M. i wspólaut., 2011. Conservation of farmland birds faces different challenges in Western and Central-Eastern Europe. Acta Ornithol. 46, 1-12.

TscharntKe T., Klein A. M., KRUess A., STEFFAN-DEWENTER I., THIES C., 2005. Landscape perspectives on agricultural intensification and biodiversity - ecosystem service management. Ecol. Lett. 8, 857-874.

TUCKER G. M., HEATH M. F., 1994. Birds in Europe: Their conservation status. Birdlife International, Cambridge.

Ursúa E., SerRano D., Tella J .L., 2005. Does land irrigation actually reduce foraging habitat for breeding lesser kestrels? The role of crop types. Biol. Conserv. 122, 643-648.

VickeRY J. A., TAllowin J. R., FEBER R. E., ASTERAKI E. J., ATKINSON P. W., FUlleR R. J., BROWN V. K., 2001. The management of lowland neutral grasslands in Britain: effects of agricultural practices on birds and their food resources. J. Appl. Ecol. 38, 647-664.

WATSON M., THIRGOOD S., 2001. Could translocation aid hen harrier conservation in the UK? Animal Conserv. 4, 37-43

WhitTingham M. J., EVANS K. L., 2004. The effects of habitat structure on predation risk of birds in agricultural landscapes. Ibis 146, 210-220.

KOSMOS Vol. 68, 1, 75-87, 2019

NATALIA HAEAS

Population Ecology Lab, Institute of Environmental Biology, Faculty of Biology, Adam Mickiewicz University in Poznań, 89 Umultowska Str., 61-614 Poznań, The Botanical Garden of the Adam Mickiewicz Unoiversity in Poznań, 165 Dabrowskiego Str., 60-594 Poznań, E-mail: natalia.krolikowska@amu.edu.pl

\section{CONSEQUENCES OF TRANSFORMATIONS IN AGRICULTURAL MANAGEMENT AND FARMLAND LANDSCAPE FOR RAPTORS}

\section{Summary}

Agrocenoses may stand out by a high natural value when serving as hosts for many rare and endangered species. However, increasing intensification of agriculture resulted in a general decrease of the quality of farmland habitats for birds and dramatic decline in abundance of many species. In this article, I discuss the effects of agricultural intensification for raptors - birds with large home ranges and placed at the top levels of food chains. I split such effects into two groups: direct (devastation of breeding sites and killing young and adult birds) and indirect one (modification and impoverishment of high quality habitats, depletion of food resources, bioaccumulation of pesticides and its consequences for birds). I characterize population status and threats for the two model raptor species occupying farmland: Montagu's Harrier Circus pygargus and Marsh Harrier Circus aeruginosus. Many raptors inhabiting agrocenoses are on the decline, while some others become adapted to these habitats. However, the negative influence of agricultural intensification on birds may become apparent only after some time, if their population dynamics follows source-sink model. As a consequence, this can result in the decline of many species that for now are relatively abundant. In the long-term, the intensification of agriculture may lead to further homogenization of animal communities inhabiting farmland. 